\title{
AFTA and the Asian Crisis: Help or Hindrance to ASEAN Intra-Regional Trade?
}

Robert J. R. Elliott** and Kengo Ikemoto*

Keywords: trade, gravity equation, ASEAN

JEL: F1, F14

**Robert J. R. Elliott is a Lecturer in Economics in the School of Economic Studies, University of Manchester.

*Kengo Ikemoto is a former Research Student in the Institute for Development Policy and Management, University of Manchester and now works for the Cabinet Office of the Government of Japan. 


\title{
AFTA and the Asian Crisis: Help or Hindrance to ASEAN Intra-Regional Trade?
}

\begin{abstract}
Using a modified gravity equation, this paper examines ASEAN intra- and extra-regional bias in bilateral trade flows and how these relationships have altered over time. We pay particular attention to the periods before and after the signing of AFTA as well as the crucial years prior to and following the Asian crisis. Given the "openness" of ASEAN countries we consider not only intra-ASEAN trade but also the effect of AFTA on non-members. We find that trade flows were not significantly affected in the years immediately following the signing of the AFTA agreement and also that the traditional stance of ASEAN countries to outward oriented economic activity has not been significantly damaged but rather stimulated by the AFTA process and/or the Asian economic crisis. We do find however, that that one effect of the Asian economic crisis was to generate a stronger desire to source imports from within the region.
\end{abstract}


The recent proliferation of regional trading blocs is striking with the signing of numerous new and overhauled preferential trade agreements (PTAs) since 1990. ${ }^{1}$ There remains however, an ongoing debate between economists and politicians as to whether regional trade agreements (RTAs) represent "building" or "stumbling" blocks (Bhagwati 1991). The welcome for the opportunities this new wave of regionalism is supposed to bring is not therefore, all encompassing with some fearing that regional economic integration corrupts and undermines progress towards global free trade expounded by the General Agreement on Tariffs and Trade (GATT) and more recently the World Trade Organisation (WTO). Others however, are more positive (see e.g. Summers 1991, Lawrence 1991, Ethier 1998, IDS 1999 and the World Bank 1999) and see any trade liberalisation as good whatever its source and PTA's as a second best means of achieving trade liberalisation when multilateral negotiations stall. ${ }^{2}$

Closer European integration and a number of regional initiatives from the United States transformed the global economic climate in the late 1980's and meant that it was increasingly important for smaller developing and newly industrialised countries to generate closer regional economic ties. One of the more influential regional

\footnotetext{
1 A PTA is an agreement between two countries where the tariff imposed between them is lower than that on goods from countries outside the agreement. PTAs include regional trade agreements between countries within a given geographical area and free trade agreements that have no tariffs between member countries but individual tariff structures with non-members.

2 In addition to existing agreements such as the European Union (EU) and the European Free Trade Association (EFTA) other new or rejuvenated regional trade agreements include the Common Market of the South (MERCOSUR, 1991), the North American Free Trade Association (NAFTA, 1994), the ADEAN Pact (ANDEAN), and the Central American Common Market (CACM) in the Americas. In Africa the 1990's saw the creation of the Union Duaniere et Economique de l'Afrique Central (UDEAC), the Common Market for Eastern and Southern African States (COMESA) and the Union Economique et Monetaire Quest-Africaine (UEMOA). According to the WTO (2001) all WTO members have taken part in at least one episode of regional integration.
} 
developments was in the Southeast Asian region where me mbers of the Association of Southeast Asian Nations (ASEAN) agreed in 1992 to establish the ASEAN Free Trade Area (AFTA) that currently has a membership of ten countries and a population of over 500 million. Moreover, the recent emergence of China as an economic power in the region following its membership of the WTO has led to a renewed vigour among ASEAN nations to pursue the goal of regional cooperation.

Broadly speaking, the last thirty years has seen a robust economic performance from ASEAN countries. One reason for this apparent success was that the engine of growth was primarily extra-regional rather than intra-regional trade and questions therefore, the need for a Southeast Asian regional grouping. Krugman (1991) introduced the notion of a "natural trading block" based on geographical proximity that could be both efficient and welfare increasing. He also noted however, that an RTA based on being a member of a political club could induce regional bias to trade patterns that can be welfare reducing if trade diversion is greater than trade creation. This raises the question of whether AFTA has any real economic rationality over its mere political and symbolic meaning.

The primary objective of this paper therefore, is to investigate the effect of AFTA and the "anticipation" effect of AFTA on intra- and extra-regional trade flows by a comparison of trade patterns before and after the start of the AFTA process. Given the "openness" of ASEAN countries it is important to consider not only intra-ASEAN trade but also the effect of AFTA on non-members trade. By doing so we hope to be able to reveal whether AFTA; (i) increases trade among members (ii) harms 
non-member countries and (iii) contributes to or undermines future liberalisation negotiations.

Any post-1992 AFTA analysis is however, further complicated by the ramifications of the Asian economic crisis that began with a massive speculative attack on the Thai baht May 14-15, 1997. The years following the crisis saw ASEAN members suffer significant structural and financial difficulties (including reduced aggregate growth and job losses) associated with large currency depreciations and capital outflows. Relatively few studies examine the period during and after the Asian crisis even though the affects on the economies of the region were often profound (Clarete et al. 2002 is one exception). For example, according to World Bank data, Indonesia moved from a GDP growth rate of $4.9 \%$ in 1997 and a financial account surplus of 10.8 (US\$ billion) in 1996 to a GDP growth rate of $-13.7 \%$ and a financial account deficit of -10.3 (US\$ billion) in 1998. Likewise, Thailand moved from a positive growth rate of $5.5 \%$ in 1996 to $-10.2 \%$ in 1998 and a change from a financial account surplus of 19.5 (US\$ billion) in 1996 to deficits of -16.9 and -14.6 (US\$ billions) in 1998 and 1999 respectively.

In this paper we are interested in whether ASEAN countries attempted to solve their problems with the help of newly strengthened intra-ASEAN relations and whether the result of the crisis was to significantly change the structure of imports and exports and result in the collapse of long-standing trade relationships. As a consequence, we address whether the aims of AFTA to increase intra-regional trade and cooperation were helped or hindered by the Asian crisis. 
The existing empirical literature suggests two main approaches for measuring the economic impact of PTAs. Partial or general equilibrium models provide an ex ante approach that includes computable general equilibrium models to empirically predict the impact of AFTA on the economy and constituent trade flows (see e.g. Imada et al. 1991, Adams and Park 1995 and DeRosa 1995). The second approach focuses on ex post investigations of bilateral trade values using the so-called gravity equation. Simple examples of the application of a gravity type approach to intra-regional trade bias of selected regional groupings (one being ASEAN) include Hamilton and Winters (1992), Frankel (1993) and Sharma and Chua (2000) while Elbadawi (1997), Frankel and Wei (1998), Endoh (1999, 2000) and Soloaga and Winters (2001) present useful extensions of the basic model.

The core methodology in this paper is based upon Endoh (2000) and Soloaga and Winters (2001) but the analysis concentrates on ASEAN intra- and extra-regional bias in bilateral trade flows and how these trade relationships have altered over time paying particular attention to the periods before and after the signing of AFTA as well as the crucial years prior to and following the Asian crisis.

The paper is organized as follows. Section 2 provides some historical background to regional cooperation in the Southeast Asian region. Section 3 describes the methodology and estimates a modified gravity equation while Section 4 discusses the results and Section 5 concludes. 


\section{Historical Overview}

Attempts at organised regional co-operation between South-East Asian countries dates back to August 1967 when the ASEAN was established with original members Indonesia, Malaysia, the Philippines, Singapore and Thailand. ${ }^{3}$

As ASEAN's initial concerns were issues of political security it was not until the 1970 's that they tried to promote greater intra-regional trade and co-ordinate industrialisation policies (based on proposals made by the United Nations sponsored studies which called for regional import substitution, Park 1999). ${ }^{4}$ In 1977 a PTA was established specifically to encourage greater intra-regional trade. The consensus from existing studies however, suggests that this initiative was disappointing (see e.g. Ariff 1994 and Garnaut and Drysdale 1994). Tan (1992) attributed this disappointment to several elements including the limited coverage of the PTA, an intra-regional trade structure that was competitive rather than complementary, and the diminishing urgency of pursuing the task because of the continued growth and development of the region.

What transformed the half-hearted attitude to co-operation were the changes in the global competitive environment during the late 1980's and 1990's. As indicated by

\footnotetext{
3 Expansions to the membership of ASEAN were Brunei in 1984, Vietnam in 1995, Myanmar and Laos in 1997 and Cambodia in 1999 and were ttempts to include the perceived "natural" trading partners of existing members. A number of other regional initiatives involving countries from this part of the world exist including the South Asian Association for Regional Cooperation (SAARC), the SAARC PTA (SAPTA), Austrialia and New Zealand's Closer Economic Relations Agreement (CER) and the South Pacific Regional Trade and Economic Cooperation Agreement (SPARTECA). See the Asian Development Outlook 2002 for an overview.

4 Within the institutional framework of ASEAN, heads of states meet annually to ensure strong regional communication and cooperation at both the technical and political level. Anwar (1994) and Pomfret (1996) both suggest ASEAN lessened military tension and contributed to political stability in the area.
} 
Menon (1996) and others, the formation of NAFTA and the EU raised questions about the access of ASEAN exports to the markets of North America and Europe. Furthermore, the competition to attract foreign direct investment (FDI) was intensifying and in recent years includes the emergence of China as a global economic power and location for Western FDI. ${ }^{5}$

In response, the founder ASEAN countries agreed to establish an ASEAN free trade area by the year 2008. This target has been continuously moved forward and AFTA was officially established among the original six countries at the beginning of 2002 (ASEAN Secretariat 2002). ${ }^{6}$ Although AFTA involves several measures to enhance regional trade such as the elimination of non-tariff barriers, the main mechanism for achieving AFTA has been the Common Effective Preferential Tariff (CEPT). As Pangestu et al. (1992) indicate, the approach of the CEPT is essentially reciprocal and sectoral, which makes it more encompassing and less cumbersome than the product-by-product approach of PTAs (Athukorala and Menon, 1997). This regime was applied to all products from ASEAN member countries defined as those that had at least 40\% ASEAN content (ASEAN Secretariat, 1995). ${ }^{7}$

\footnotetext{
${ }^{5}$ ASEAN secretary general Rodolfo Sererino has recently commented that the Southeast Asian region should "integrate the regional economy to a closer degree to the integration of the Chinese market". The first round of high-level talks aimed at establishing a FTA between ASEAN and China started in May 2002. When implemented the worlds largest FTA will generate estimated trade worth $\$ 1.2$ trillion.

6 Under an amended plan in 1995, the reduction of existing tariff rates to $20 \%$ was to be effective within a time frame of five to eight years from 1st J anuary 1993 and are to be cut further to $0-5 \%$ by 2003. In 1998 the ASEAN governments agreed that the original six countries would aim to reduce tariffs to under $5 \%$ by 2002 . Around $95 \%$ of intra-ASEAN trade tariffs representing $90 \%$ of intra-ASEAN trade is now in the $0-5 \%$ tariff range with the average tariff now $3.2 \%$.

7 Appendix A provides details and indicates how this schedule is flexibly managed depending on the preferences of different countries over a range of sectors.
} 
These characteristics of AFTA and the earlier less effective experience of regional integration might lead one to question the feasibility of a substantial expansion of regional trade. It must also be remembered that ASEAN countries have achieved significant economic growth and development based on independent outward-looking policies. OECD (1993) argues, therefore, that AFTA might not be a serious regional economic initiative but at best a hedge against other regional integration initiatives or a temporary failure of multilateral negotiations under the GATT-WTO regime. It may be conjectured however, that the shock and upheaval caused by the Asian crisis provided ASEAN countries with renewed enthusiasm for maintaining and strengthening regional links and to increase intra-regional trade to counter economic uncertainty in the region and the rise of regional blocs elsewhere.

\section{Methodology: A Modified Gravity Model Approach}

The gravity equation has experienced something of a revival in recent years and provides a natural framework and a useful multivariate approach for assessing the impact of regional trading blocs on the level and direction of bilateral trade flows. In addition to its continued success at predicting bilateral trade patterns it has seen renewed interest from the new economic geography literature as well as increased confidence in its traditionally weak theoretical foundations arising primarily from the so-called "new trade" theory. ${ }^{8}$ Indeed, Elbadawi (1997) argues that the successful outcome of the gravity equation may stem from its ability to capture factors that conventional factor endowment theory cannot easily accommodate such as

8 See Evenett and Keller (2002) for a discussion of theories that explain the gravity equation's success. The underlying theory can be found in Deardorff (1984) and Helpman and Krugman (1985). See Anderson (1979), Bergstrand (1985) and Sanso et al. (1993) for further discussion. 
intra-industry trade (by considering, for example, economic size and scale economies) and the dramatic reallocation of resources following trade liberalisation (by introducing dummy variables). ${ }^{9}$

An example of a gravity equation where trade is positively related to two countries incomes and negatively related to the distance between them (reflected by transport costs) takes the following form (in natural logarithms); ${ }^{10}$

$\log M_{i j}=\log \alpha_{0}+\alpha_{2} \log Y_{i}+\alpha_{2} \log Y_{j}+\alpha_{3} \log N_{i}+\alpha_{4} \log N_{j}+\alpha_{5} \log D_{i j}+\log u_{i j}$

where $\mathrm{M}_{i j}$ is the imports from country $i$ to $j, Y$ is income, $N$ is population, $D_{i j}$ is the distance between economies $i$ and $j$ and $u_{i j}$ is the log normally distributed error term where $\mathrm{E}\left(\log u_{i j}\right)=0$. Assuming no PTAs, equation (1) explains trade between countries $i$ and $j$ and behaves as a counterfactual.

In this paper we modify the basic gravity equation where our estimating equation in natural $\operatorname{logs}$ (with expected signs in brackets) is shown in equation (2). ${ }^{11}$

\footnotetext{
9 Previous developments included the addition of a population variable to reflect the role of scale economies (e.g. Linnemann 1966), a dummy variable to represent the existence of preferential trade arrangements (e.g. Aitken 1973), the difference of per capita income and the absolute income level as variables to capture the so-called Linder Hypothesis and differences in factor endowments respectively (see e.g. Elbadawi 1997 and others). Linder (1961) argued countries with similar income level have incentives to trade with each other. In addition to distance and adjacency variables, recent studies also include a geographical measure of "remoteness" although our concentration on the ASEAN region makes its inclusion unnecessary.

10 This is a variation on the original Tinbergen (1962) and Pöylönen (1963) specifications. 11 All regressions are estimated using OLS in TSP. Estimations using a Tobit model (to account for the fact that trade values are bounded from below at zero) resulted in very similar results. See Soloaga and Winters (2001) for a discussion.
} 


$$
\begin{gathered}
\log \left(M_{i j}\right)=\log \beta_{0}+\beta_{1} \log \left(G D P_{i}\right)+\beta_{2} \log \left(G D P_{j}\right)+\beta_{3} \log \left(P G D P_{i}\right)+\beta_{4} \log \left(P G D P_{j}\right) \\
\left.+\beta_{5} \log \left(D_{i j}\right)+\beta_{6} \log \left(\mid P G D P_{i}-P G D P_{j}\right)\right)+\beta_{7} C O M_{i j}+\beta_{8} A D J_{i j}+\sum \beta_{9 k} R T A_{i j k} \\
(-) \quad(+ \text { or }-) \quad(+) \\
+\sum \beta_{10 k} i m R T A_{i j k}+\sum \beta_{11 k} \text { exRTA }_{i j k}+\log u_{i j} \\
(+ \text { or - }) \\
(+ \text { or }-)
\end{gathered}
$$

where $M_{i j}$ is the US dollar value of imports of country $i$ from trade partner $j .^{12}$ $G D P_{i(j)}$ is country $i(j)$ 's GDP, $P G D P_{i(j)}$ is country $i(j)$ 's per capita GDP, $D_{i j}$ is the distance between capital cities, $C O M_{i j}$ is a complementarity index between countries $i$ and $j, A D J_{i j}$ is a dummy variable that is 1 is two countries share a common land border and 0 otherwise, $R T A_{i j k}$ is 1 if both countries $i$ and $j$ belong to RTA $k$ and 0 otherwise, similarly imRTA is 1 if only the import country $i$ belongs to RTA $k$ and 0 otherwise and likewise, exRTA is 1 if only the export country $j$ belongs to RTA $k$ and 0 otherwise. The RTA's considered in this study are ASEAN, EU, NAFTA and APEC. ${ }^{13}$ Finally, $u_{i j}$ is the $\log$ normally distributed error term, where $\mathrm{E}\left(\log u_{i j}\right)=0$.

We estimate several specifications of equation (2). To enable us to make comparisons before and after the AFTA process started as well as prior to, and following the Asian crisis our data cover the period 1982 to 1999 . We provide estimations for six distinct time periods, three five-year periods 1983-1987, 1988-1992, 1993-1997 as well as 1998-1999 and two summary periods 1983-1997 and 1993-1999. ${ }^{14}$

\footnotetext{
12 The original gravity model has exports as the dependent variable. Equation (2) was estimated for exports, imports and total trade with similar results. For reasons of data accuracy we report the results with imports as our dependant variable.

13 Note that some RTA's increase their membership over time. In this study however, each regional group is defined for a consistent country membership. See Appendix B for a list of countries included in our ASEAN, EU, NAFTA and APEC dummies.

14 The pooling of the data has the effect of smoothing the effects of business cycles, economic shocks and trade imbalances that could affect any given year. All results were
} 
There are two excluded variables that require further discussion. The first is the real exchange rate. If our regressions were simple yearly cross sections then real exchange rates are not relevant as it is not possible to tell whether a currency is over or undervalued. With pooled data however, competitiveness via the real exchange rates matters. If we are to take account of the effect of the Asian crisis on trade relationships it would seem appropriate to have a measure that can pick up the effect of changes in the real exchange rates over the period of study. In this paper we experimented with a number of real exchange rate variables although the existing gravity literature provides limited guidance. Our approach was to include a single variable where country $i$ 's real exchange rate relative to country $j$ was defined as country i's local currency value of one unit of country j's currency multiplied by j's GDP deflator and divided by country $i$ 's GDP deflator where $i$ is the importer and $j$ is the exporter country. See Appendix C for a graphical representation. This is similar to Soloaga and Winters (2001) who include two variables, one for each country where country $i(j)$ 's real exchange rate was defined as the local currency value of one US\$ multiplied by the US GDP deflator and divided by country $i(j)$ 's GDP deflator. In both cases the means over our periods are set to zero so that movements relative to the mean reflect real exchange rate effects. The inclusion of our variable made little difference to overall results while the Soloago and Winters (2001) results were often inconsistent. The mixed evidence from previous studies makes the results using real exchange rates questionable and are thus, not reported in this paper. ${ }^{15}$ The other variable that is usually included in gravity equations is a

reestimated using 1993-1996 instead of 1993-1997 but no discernible differences were observed.

15 Results of equation (2) including our exchange rate variables are available from the author upon request. 
common language dummy but as we are primarily interested in a group of countries that all have their own distinct language the results are not reported.

The structure of equation (2) differs from the standard gravity model in two main ways. First, we include an index of complementarity. One of the characteristics of the basic gravity equation is that it does not explicitly include a factor endowment variable as, although income level differences reflect factor endowment differences, they may also explain product differentiation or demand dissimilarity (see e.g. Deardorff 1984 and Frankel 1997). A complementarity index $\left(C O M_{i j}\right)$ based on Drysdale (1967) is included to directly capture factor endowment differences and is given by;

$\left.C O M_{i j}=\sum\left\{\left(X_{i}^{k} / X_{i}\right)\left(M_{w}-M_{i}\right) / M_{w}^{k}-M_{i}^{k}\right)\left(M_{j}^{k} / M_{j}\right)\right\}$

where $X_{i}^{k}$ is country $i$ 's exports (of commodity $k$ ), $M_{j}^{k}$ is country $j$ 's imports (of commodity $k$ ) and $M_{w}^{k}$ is world imports (of commodity $k$ ). $C O M_{i j}$ is able to separate the impact of the commodity composition from other factors that drive trade flows and represents the extent of the fit between the structure of exports and imports of bilateral trade partners based on the assumption that traded commodities reflect 
factor endowments. ${ }^{16}$ The index is calculated at the three-digit level of the Standard International Trade Classifications (SITC). ${ }^{17}$

A second methodological issue concerns the definition and measurement of trade creation and trade diversion where a gravity approach is seen as a more elaborate method of measurement (Hine 1994). ${ }^{18}$ Aitken (1973) was one of the first studies to attempt to capture trade creation and trade diversion by the inclusion of a regional dummy with additional calculations for the counterfactual residual to capture the trade diversion and the net trade creation in a Vinerian sense. Elbadawi (1997), Bayoumi and Eichengreen (1997), Frankel (1997), Frankel and Wei (1998) introduced a second dummy to show the regional integration effect on the trade with non-members as well as an intra-bloc dummy. The first two studies, however, do not separate the diversionary effect of imports and exports, while Frankel and Wei (1998) ignore the possible effect of regional integration on exports to non-members (Soloaga and

16 Drysdale (1967) attempted to explain the causes of bi lateral trade by dividing trade intensity (I) into complementarity (C) and bias (B) where I $=\mathrm{C} \times \mathrm{B}$. Complementarity is a product of comparative advantage if we assume that import and export patterns reflect their resource endowment and represents the extent to which economies resources and production structures are complementary while bias is what remains after accounting for complementarity and includes geographical, social, historical, cultural and institutional ties.

17 A number of studies argue that the three-digit SITC level captures commodities that are produced using a similar technology and factors (see e.g. Greenaway and Milner 1986, and Menon 1996).

18 Viner (1950) first referred to trade creation and trade diversion in the context of the wel fare effects of trade barriers. Early approaches however, tended to compare actual import value data for a post regional integration period with counterfactual import values estimated by using only pre-integration data. F or example, Truman (1969) assumed the pre-integration shares of imports in apparent consumption to be unchanged, whilst Balassa (1967, 1974, 1975) assumed that the pre-integration import elasticity would have continued in the post-integration period. Truman interpreted the increase in import share, compared to the antimode to mean trade creation and the decrease in the rest of the world share to mean trade diversion, while Balassa argued that increased intra-el asticity was gross trade creation, increased elasticity from all sources was trade creation and decreased elasticity from non-area sources was trade diversion. Kruger (1999) examined NAFTA's trade creation and trade diversion effects using industry level data. Other approaches include Verdoorn and Schwartz (1972) who incorporated relative prices into the model and Prewo (1974) who combined input-output tables and the gravity model as a general equilibrium approach 
Winters, 2001). We follow Endoh $(1999,2000)$ and pursue the relatively new approach of employing three dummies per region. ${ }^{19}$

Including dummies for what we define as "import trade diversion" and "export trade diversion" enables us to tell whether an increase in an institutional dummy is due to an increase in intra-regional trade, a decrease in trade between members and non-members, or both. In our estimates "RTA" captures the total intra-regional trade bias or trade creation defined in a Johnson (1962) sense. The dummy "imRTA" captures the extra-regional import bias of intra-RTA trade or the import trade diversion as a result of changes to the import structure of the RTA where a negative and significant coefficient indicates that member countries have switched to importing from members rather than non-members. Finally, "exRTA" captures the extra-regional export bias of the RTA to the rest of the world or the export trade diversion where a negative and significant coefficient means that the RTA has resulted in a member country preferring to export to members rather than non-members. ${ }^{20}$

In the first instance, as a method of explaining the world's bilateral trade patterns, we estimate a relatively simple gravity equation with a single intra-regional bias dummy

\footnotetext{
19 We acknowledge however, that in Viners original welfare context we cannot make unambiguous conclusions about the degrees of trade creation and trade diversion without knowing exact tariff structures and relative price changes (World Bank 1999). Soloaga and Winters (2001) also include three dummy variables but differ in their interpretation of trade creation and trade diversion.

20 The term export trade diversion was first used by Endoh (1999) and differs from definitions of trade diversion given by Balassa (1967), J ohnson (1962) and Viner (1950) Elbadawi (1997) and Endoh (1999) state that whether a RTA is trade creating or diverting depends on the sign of the RTA dummies and not their movements over time. The size of the coefficient however, can be affected by the country sample size. As a consequence, it is more appropriate to pay attention to changes in the coefficient through the RTA formation period rather than the level itself.
} 
for four PTA's (ASEAN, APEC, NAFTA and the EU). ${ }^{21}$ Second, we investigate the degree of the trade creation and trade diversion as a result of AFTA by incorporating our two additional dummies, imRTA and exRTA. The degree of trade creation and trade diversion for each RTA is extracted from the movement of the coefficients on the three dummy variables. Finally, we estimate equation (2) for the intra-ASEAN trade only to better understand the intra-regional trade flows for the same five yearly periods.

\section{$4 \quad$ Results}

Table 1 presents the results for the simple gravity equation. Regional dummy variables are included all together and then separately and jointly for the case of ASEAN and APEC. The signs of the coefficients on the variables in the first half of Table 1 are as expected and are generally highly significant. The coefficient on GDP for example, is generally between 0.7 and 0.8 suggesting that trade increases as economic capacity grows. ${ }^{22}$ We also find the traditional negative sign on distance and positive sign on our common border variable. The complementarity index also records a positive and significant coefficient and seems to support the hypothesis that trade is greater when two countries endowments (reflected in the structure of the commodities traded) are complementary. Only per capita GDP differences records a decline in significance (and even changes sign) over time. One possible explanation

\footnotetext{
21 I deally we would have liked to include all possible RTA's to avoid bias in the results. By including the main groupings in terms of trade volumes however, the bias is likely to be minimal. See Endoh (1999) for further discussion.

22 Frankel (1993) notes that a coefficient of less than one reflects the phenomenon that the smaller the country the greater the trade/production ratio.
} 
is the Linder hypothesis that emphasises income similarity as the driver of trade instead of income differences.

The intra-regional dummies for regressions (1) and (2) are positive for ASEAN and APEC implying that countries located within these regions do trade more with each other over and above the levels predicted by the basic explanatory variables. In regression (3) we observe that the EU and NAFTA dummies are also generally positive and significant. ${ }^{23}$ The inclusion of all four regional groupings in regression (4) reveals however, that the NAFTA coefficient was negative and significant for the first two periods (prior to the setting up of NAFTA) before becoming positive. Our results, showing a positive and significant ASEAN effect, differ from a number of previous studies such as Sharma and Chua (2000) and Soloaga and Winters (2001) who both observe a negative relationship albeit for a different estimating equation and country coverage but are similar to Frankel et al. (1995) and Endoh (2000) who recorded positive and significant coefficients for APEC. Note that the ASEAN coefficient falls between 1993-1997 after the AFTA process started and it was not until after the Asian economic crisis that the trend reverted to an upward one. One possible suggestion is that it took a regional economic shock of the form of the currency crisis to trigger the latent forces of ASEAN regional integration that could not be stimulated by mere political rhetoric.

Observe that when we include both ASEAN and APEC dummies the ASEAN coefficient is significantly lower. This is consistent with Frankel (1993) who

\footnotetext{
23 Previous studies have included a variety of European regional dummies that have generally been found to be insignificant. The results tend to differ depending on the country coverage and method of estimation. When we included EU 12 or EU 15 dummies the variable was also insignificant.
} 
observed that in 1980 and 1990 the ASEAN dummy was only significant when no other Asian bloc dummies were included and concluded that ASEAN did not seem to be an appropriate bloc around which to draw a border.

This leads us to enquire whether the AFTA process has been trade creating or trade diverting and whether ASEAN is a discriminating bloc or exhibits "open regionalism". ${ }^{24}$ The lack of a consistent upward trend in the ASEAN dummy over our period of analysis deserves closer examination. In Table 2 we include our two additional dummies to represent the case where only the import or export country is a member of the RTA. As previously discussed, AFTA is trade creating if the ASEAN coefficient increases and that of the others do not change after the AFTA process started and the AFTA is trade diverting in two cases; (i) ASEAN member's welfare is reduced if the ASEAN coefficient increases and that of imASEAN decreases, (ii) non-member's welfare is reduced if the ASEAN coefficient increases and that of exASEAN decreases.

In Table 2 the three regional dummies are generally significant and justifies their inclusion. A comparison of the RTA coefficients with Table 1 demonstrates that the largest differences are for the ASEAN dummy (the EU and NAFTA coefficients remain relatively stable).

Concentrating on ASEAN, observe that ASEAN, imASEAN and exASEAN all record positive and significant coefficients with the former the largest in all periods. The fact that all three dummies are positive and significant means that members and

24 For a discussion of the concept of "open regionalism" see Bergsten (1997) and Yamazowa (1992). 
non-members have traded with each other more than the hypothetical trade level. Examining coefficient changes over time we observe again that $A S E A N$ falls between 1993 and 1997 and then rises while $i m A S E A N$ increases until 1997 (despite the ongoing AFTA process) and then decreases while exASEAN demonstrates a consistent rise (with a significant jump after the crisis). Considered jointly, the imASEAN and exASEAN coefficients reveal the extent of the extra-ASEAN trade bias over the period. The generally increasing trend means that there has been a negative trade diversion effect. More specifically, the upward trend in exASEAN indicates that negative export trade diversion has been strengthening and means that the volume of trade between members and non-members has been increasing (and not falling as would be the case with trade diversion and welfare losses to non-members). The slight fall in imASEAN after 1997 does reveal a weakening of the negative import trade diversion effect as ASEAN members begin to prefer to import goods from members rather than non-members but the effect is only small against a large increase in intra-regional trade in general. These results seem to suggest that ASEAN countries retained their openness and outward orientation despite AFTA and the Asian economic crisis.

One explanation for the lack of any export diversionary effect and the slight weakening of the negative import diversion effect after 1997 is that ASEAN countries may have increased their exports to the rest of the world due to changes in their real exchange rates (as exASEAN rose sharply after 1997 in Table 2). The devaluation of ASEAN currencies during the Asian crisis should have contributed to an increase in the competitiveness of their products with the rest of the world (as exports and 
imports became less and more expensive respectively). ${ }^{25}$ Appendix C illustrates the real exchange rate of ASEAN countries and demonstrates the simultaneous depreciation of ASEAN currencies relative to non- member countries and the relative stability of intra-ASEAN rates after 1997 that may explain some of the trend. The inclusion of a real exchange rate variable made little difference to the results however (see Section 3 for a discussion).

Finally, in Table 3 we investigate the nature of the AFTA process on ASEAN bilateral trade. The observations of basic gravity variables in Table 3 are broadly in line with the results in Table 1 although two related findings are worth mentioning. First the ASEAN coefficient increases constantly over time especially after the AFTA formation period. This suggests that the AFTA process may have had some effect on intra-regional trade ever since its inception that has accelerated since the Asian crisis. Second, there is little difference in the coefficients on the GDP variables between the pre- and the post crisis period while the ASEAN coefficient rose. This supports the argument that even accounting for the upheavals of the Asian crisis there are no dramatic changes in the way other economic factors determine intra-ASEAN trade flows.

\section{Discussion}

Using a modified gravity equation, this paper investigates the effect of AFTA on world and regional trade patterns. Our first main finding is that trade flows were not

25 This competitive effect is partly offset by the increase in the prices of intermediate products and inputs in the manufacturing process. 
significantly affected in the years immediately following the signing of the AFTA agreement in 1993 and reinforces the findings of previous studies. Indeed, the degree of trade creation was lower than the preceding period 1988-1992. When the gravity equation was re-estimated for intra-ASEAN trade only however, we did find some evidence of a positive AFTA effect that although limited at first, gradually increased. It should be noted however, that institutional progress by ASEAN governments at this time was relatively limited.

One possible explanation for the fall in trade creation immediately following 1993 was the emergence of credible competition for market share from the new industrial and exporting powers of China, South American and Eastern Europe. Similarly other regional trade agreements such as the EU and NAFTA and associated agreements between these groupings and countries in Eastern Europe, the Middle East and North Africa may have exhibited their own trade diversion effects. The observation from Table 2 that the coefficient of NAFTA dramatically increases in 1990s while the coefficient of exNAFTA decreases (and is negative) supports this conjecture.

Our second finding is that the Asian economic crisis was not a hindrance to the aims of AFTA but rather may have worked as a trigger for a further acceleration of the process and de facto economic integration itself. Indeed, evidence from Table 2 also suggests that the effect of the Asian economic crisis was to generate a stronger desire to source imports from within the region (even though the effect seems to have been relatively small). A second explanation for the weakening of the negative import diversion effect after the Asian crisis may reflect the consensus that prior to this date 
that although ASEAN's success was based on its outward orientation, perceived problems of credibility and confidence in the region by the industrialised world meant that ASEAN countries were forced to turn inwards and to focus on their local markets. In response, ASEAN governments have made significant efforts to promote the AFTA process in the midst of Asian crisis, for example at the ASEAN summit in 1998 when the final date for completion of AFTA was bought forward. Finally however, it can be stated that the traditional stance of ASEAN countries to outward oriented economic activity has not been significantly damaged but rather stimulated by the AFTA process and/or the economic crisis resulting in no detrimental welfare effects for the rest of the world

Recent developments suggest that ASEAN continues to make efforts to accelerate institutional progress towards regional integration through both widening its membership to include the entire Southeast Asian region and deepening its policy coverage to non-trade areas and pursuing wider integration possibilities beyond the region such as proposing economic cooperation with other regions and countries such as China and Japan. It is, however, crucially important that there is a strong economic rational to regional integration. In this sense, developments in this region have benefited from support from multinational corporations and an additional explanation for the recent rise in intra-ASEAN trade includes manufacturing's increasing reliance on an intra-regional production networks where parts, components and other intermediate goods are produced across the ASEAN region and bought together in one location for final assembly ( $\mathrm{Ng}$ and Yeats 1999, Arndt 2001, Guiheux and Lecler 2000). 
There remain however, a number of questions raised by this study. First, the short-run adjustment costs following the AFTA process and the Asian crisis are an important issue both economically and politically. There is still little reference to this subject for the case of ASEAN (early studies include Khalifah 1996, Menon 1996 and Brülhart and Thorpe 2000). ${ }^{26}$ Secondly, the long-term dynamic gains that ASEAN governments wished to peruse from AFTA such as the attraction of FDI, accumulation of capital stock, technological progress, increasing product variety, evolving comparative advantage structures and so on may be currently being realised although it is still too early to observe them empirically (early studies include Madani 2001 and Bende-Nabende and Slater 2001).

26 Concerns about domestic industrial adjustment have already resulted in some countries calling for a rescheduling and rethinking of the product coverage (Menon 1996). Producers in Thailand and Malaysia for example, have requested more protective measures at least in the short-term and Malaysia introduced the Approved Permit System (APS) in April 1994 to restrict imports (Menon, 1996). 
Table 1. Modified Gravity model estimates investigating intra-regional bias

\begin{tabular}{|c|c|c|c|c|c|c|c|c|c|c|c|c|}
\hline variable & & & Equati & ion (1) & & & & & Equati & ion (2) & & \\
\hline & 1983-87 & $1988-92$ & $1993-97$ & $1998-99$ & 1983-97 & 1983-99 & $1983-87$ & 1988-92 & $1993-97$ & 1998-99 & 1983-97 & 1983-99 \\
\hline $\mathrm{C}$ & $-25.79 * * *$ & $-24.36 * * *$ & $-25.81 * * *$ & $-25.50 * *$ & $-23.63 * * *$ & $-23.73 * * *$ & $-24.84 * * *$ & $-23.46 * * *$ & $-24.13 * * *$ & $-23.86 * * *$ & $-22.54 * * *$ & $-22.59 * * *$ \\
\hline & $(-57.08)$ & $(-56.13)$ & $(-58.93)$ & $(-36.24)$ & $(-99.46)$ & $(-106.62)$ & $(-61.47)$ & $(-62.30)$ & $(-63.12)$ & $(-38.61)$ & $(-106.73)$ & $(-114.31)$ \\
\hline LGDPR & $0.74 * * *$ & $0.72 * * *$ & $0.74 * * *$ & $0.75 * * *$ & $0.71 * * *$ & $0.71 * * *$ & $0.72 * * *$ & $0.69 * * *$ & $0.71 * * *$ & $0.72 * * *$ & $0.69 * * *$ & $0.69 * * *$ \\
\hline & (61.49) & $(63.89)$ & ( 67.27) & $(42.42)$ & ( 108.29) & ( 116.23) & $(65.22)$ & (69.36) & ( 72.11) & (45.57) & (115.21) & (123.69) \\
\hline LGDPP & $0.72 * * *$ & $0.73 * * *$ & $0.80 * * *$ & $0.78 * * *$ & $0.73 * * *$ & $0.73 * * *$ & $0.70 * * *$ & $0.70 * * *$ & $0.77 * * *$ & $0.75 * * *$ & $0.70 * * *$ & $0.71 * * *$ \\
\hline & $(59.98)$ & $(64.56)$ & $(72.22)$ & (44.16) & (110.47) & ( 118.91) & (63.51) & ( 70.19) & ( 77.72) & (47.50) & ( 117.67) & ( 126.73) \\
\hline LPGDPR & $0.21 * * *$ & $0.14 * * *$ & $0.11 * * *$ & $0.15 * * *$ & $0.14 * * *$ & $0.14 * * *$ & $0.24 * * *$ & $0.18 * * *$ & $0.14 * * *$ & $0.18 * * *$ & $0.17 * * *$ & $0.17 * * *$ \\
\hline & ( 17.05) & (13.50) & (11.07) & ( 8.96) & (21.57) & (23.18) & (21.26) & (19.10) & (15.42) & (12.31) & (29.31) & (31.58) \\
\hline LPGDPP & $0.30 * * *$ & $0.15 * * *$ & $0.10 * * *$ & $0.04 * *$ & $0.16^{* * *}$ & $0.15 * * *$ & $0.33^{* * *}$ & $0.19 * * *$ & $0.13^{* * *}$ & $0.08 * * *$ & $0.20 * * *$ & $0.18 * * *$ \\
\hline & (23.92) & $(14.45)$ & $(10.23)$ & ( 2.58) & (25.68) & (24.92) & (28.79) & (20.02) & (14.46) & ( 5.17) & (33.73) & (33.40) \\
\hline LGAP & $0.07 * * *$ & $0.06 * * *$ & -0.01 & -0.01 & $0.03 * * *$ & $0.02 * * *$ & $0.08 * * *$ & $0.06^{* * *}$ & -0.01 & -0.01 & $0.03 * * *$ & $0.03 * * *$ \\
\hline & $(5.75)$ & $(4.87)$ & $(-0.62)$ & $(-0.75)$ & ( 4.05$)$ & ( 3.64$)$ & ( 6.66$)$ & $(6.24)$ & $(-0.60)$ & $(-0.45)$ & $(5.15)$ & $(4.81)$ \\
\hline LDIS & $-0.67 * * *$ & $-0.60 * * *$ & $-0.57 * * *$ & $-0.57 * * *$ & $-0.62 * * *$ & $-0.62 * * *$ & $-0.74 * * *$ & $-0.67 * * *$ & $-0.64 * * *$ & $-0.65 * * *$ & $-0.69 * * *$ & $-0.69 * * *$ \\
\hline & $(-38.72)$ & $(-37.73)$ & $(-38.07)$ & $(-23.21)$ & $(-66.36)$ & $(-70.39)$ & $(-47.46)$ & $(-47.76)$ & $(-48.38)$ & $(-29.62)$ & $(-81.99)$ & $(-87.19)$ \\
\hline $\mathrm{ADJ}$ & $0.35^{* * * *}$ & $0.49 * * *$ & $0.44 * * *$ & $0.46 * * *$ & $0.43 * * *$ & $0.44 * * *$ & $0.35 * * *$ & $0.52 * * *$ & $0.47 * * *$ & $0.49 * * *$ & $0.44 * * *$ & $0.45^{* * *}$ \\
\hline & ( 4.63$)$ & $(6.94)$ & ( 6.58$)$ & ( 4.24) & (10.30) & (11.08) & ( 5.05$)$ & $(8.22)$ & ) & ( 5.06) & (11.64) & (12.62) \\
\hline $\mathrm{COM}$ & $1.02 * * *$ & $1.24 * * *$ & $1.15^{* * *}$ & $1.28 * * *$ & $1.13^{* * *}$ & $1.15^{* * *}$ & $1.07 * * *$ & $1.18^{* * *}$ & $1.04 * * *$ & $1.14 * * *$ & $1.10^{* * *}$ & $1.11 * * *$ \\
\hline & $(19.85)$ & $(21.24)$ & (20.10) & (15.22) & (35.00) & (38.06) & $(22.92)$ & (22.59) & (20.31) & (15.19) & (37.79) & (40.64) \\
\hline Intra-region & & & & & & & & & & & & \\
\hline ASEAN & $1.78 * * *$ & $1.75 * * *$ & $1.67 * * *$ & $1.72 * * *$ & $1.60 * * *$ & $1.61 * * *$ & & & & & & \\
\hline & (14.99) & $(16.05)$ & $(16.04)$ & (10.07) & $(24.75)$ & (26.62) & & & & & & \\
\hline APEC & & & & & & & $1.27 * * *$ & $1.30 * * *$ & $1.23 * * *$ & $1.27 * * *$ & $1.24 * * *$ & $1.25 * * *$ \\
\hline & & & & & & & (37.31) & (42.69) & $(42.65)$ & (26.98) & $(67.81)$ & ( 72.78) \\
\hline Adjusted $\mathrm{R}^{2}$ & 0.73 & 0.74 & 0.73 & 0.73 & 0.74 & 0.74 & 0.77 & 0.79 & 0.79 & 0.78 & 0.79 & 0.79 \\
\hline F-Statistic & $1787.19 * * *$ & $1860.23 * * *$ & $1819.54 * * *$ & $713.96 * * *$ & $5714.21 * * *$ & $6511.43^{* * *}$ & $2251.66^{* * *}$ & $2497.03^{* * *}$ & $2444.35^{* * *}$ & $961.77 * * *$ & $7378.55^{* * *}$ & $8433.17 * * *$ \\
\hline Obs & 5927 & 5943 & 5950 & 2380 & 17820 & 20200 & 5927 & 5943 & 5950 & 2380 & 17820 & 20200 \\
\hline
\end{tabular}




\begin{tabular}{|c|c|c|c|c|c|c|c|c|c|c|c|c|}
\hline variable & & & Equati & ion (3) & & & & & Equati & ion (4) & & \\
\hline & 1983-87 & $1988-92$ & 1993-97 & $1998-99$ & 1983-97 & 1983-99 & 1983-87 & $1988-92$ & \begin{tabular}{|l|l|}
$1993-97$ \\
\end{tabular} & 1998-99 & 1983-97 & 1983-99 \\
\hline $\mathrm{C}$ & $-25.65 * * *$ & $-24.20 * * *$ & $-25.48 * * *$ & $-25.09 * * *$ & $-23.45 * * *$ & $-23.53 * * *$ & $-25.66 * * *$ & $-24.36 * * *$ & $-24.72 * * *$ & $-24.53 * * *$ & $-23.07 * * *$ & $-23.12 * * *$ \\
\hline & $(-56.25)$ & $(-55.34)$ & $(-57.85)$ & $(-35.14)$ & $(-98.09)$ & $(-105.10)$ & $(-61.71)$ & $(-62.73)$ & $(-62.85)$ & $(-38.53)$ & $(-106.67)$ & $(-114.23)$ \\
\hline LGDPR & $0.74 * * *$ & $0.71 * * *$ & $0.74 * * *$ & $0.75 * * *$ & $0.71 * * *$ & $0.71 * * *$ & $0.72 * * *$ & $0.70 * * *$ & $0.71 * * *$ & $0.72 * * *$ & $0.69 * * *$ & $0.69 * * *$ \\
\hline & $(60.72)$ & ( 63.09) & ( 66.47) & (41.84) & ( 107.06) & (114.90) & (65.41) & (69.68) & ( 71.98) & (45.53) & ( 115.02$)$ & ( 123.48) \\
\hline LGDPP & $0.72 * * *$ & $0.72 * * *$ & $0.79 * * *$ & $0.78 * * *$ & $0.72 * * *$ & $0.73 * * *$ & $0.71 * * *$ & $0.71 * * *$ & $0.77 * * *$ & $0.76 * * *$ & $0.70 * * *$ & $0.71 * * *$ \\
\hline & $(59.22)$ & $(63.75)$ & ( 71.40) & (43.57) & ( 109.23) & (117.58) & $(63.71)$ & ( 70.50) & ( 77.55) & (47.45) & ( 117.43$)$ & ( 126.50$)$ \\
\hline LPGDPR & $0.21 * * *$ & $0.14 * * *$ & $0.11 * * *$ & $0.15 * * *$ & $0.14 * * *$ & $0.14 * * *$ & $0.25 * * *$ & $0.19 * * *$ & $0.15^{* * *}$ & $0.19 * * *$ & $0.17 * * *$ & $0.17 * * *$ \\
\hline & (16.96) & (13.45) & (11.07) & $(8.95)$ & (21.57) & (23.18) & (21.89) & (19.78) & (16.00) & (12.80) & (30.01) & (32.36) \\
\hline LPGDPP & $0.30 * * *$ & $0.15 * * *$ & $0.10 * * *$ & $0.04 * *$ & $0.16 * * *$ & $0.15^{* * *}$ & $0.33 * * *$ & $0.20 * * *$ & $0.14 * * *$ & $0.08 * * *$ & $0.20 * * *$ & $0.18 * * *$ \\
\hline & $(23.84)$ & (14.41) & $(10.22)$ & $(2.56)$ & (25.68) & ( 24.93) & ( 29.42) & (20.72) & (15.04) & ( 5.67) & (34.44) & (34.19) \\
\hline LGAP & $0.08 * * *$ & $0.06 * * *$ & -0.01 & -0.01 & $0.03 * * *$ & $0.03 * * *$ & $0.09 * * *$ & $0.08 * * *$ & 0.00 & 0.00 & $0.04 * * *$ & $0.04 * * *$ \\
\hline & $(5.89)$ & $(5.07)$ & $(-0.75)$ & $(-0.83)$ & ( 4.35$)$ & ( 3.96) & $(7.56)$ & $(7.40)$ & $(0.16)$ & $(0.04)$ & ( 6.56) & $(6.33)$ \\
\hline LDIS & $-0.65 * * *$ & $-0.58 * * *$ & $-0.57 * * *$ & $-0.57 * * *$ & $-0.61 * * *$ & $-0.61 * * *$ & $-0.70 * * *$ & $-0.62 * * *$ & $-0.61 * * *$ & $-0.62 * * *$ & $-0.65 * * *$ & $-0.65 * * *$ \\
\hline & $(-35.55)$ & $(-34.54)$ & $(-35.73)$ & $(-22.05)$ & $(-61.07)$ & $(-64.96)$ & $(-41.48)$ & $(-41.31)$ & $(-42.85)$ & $(-26.56)$ & $(-71.86)$ & $(-76.57)$ \\
\hline $\mathrm{ADJ}$ & $0.30 * * *$ & $0.43^{* * *}$ & $0.35 * * *$ & $0.35 * * *$ & $0.35 * * *$ & $0.35 * * *$ & $0.34 * * *$ & $0.50 * * *$ & $0.42 * * *$ & $0.41 * * *$ & $0.41 * * *$ & $0.41 * * *$ \\
\hline & ( 3.77$)$ & ( 5.88$)$ & ( 5.07$)$ & ( 3.17$)$ & ( 8.13) & (8.68) & ( 4.73$)$ & $(7.81)$ & ( 6.73) & ( 4.22) & ( 10.46) & (11.23) \\
\hline $\mathrm{COM}$ & $1.01 * * *$ & $1.24 * * *$ & $1.15^{* * *}$ & $1.28 * * *$ & $1.12 * * *$ & $1.14 * * *$ & $1.05 * * *$ & $1.19 * * *$ & $1.04 * * *$ & $1.09 * * *$ & $1.10 * * *$ & $1.10^{* * *}$ \\
\hline & (19.80) & (21.24) & (20.06) & (15.19) & ( 34.94) & (38.00) & $(22.57)$ & (22.98) & (20.36) & ( 14.52) & (37.80) & (40.50) \\
\hline Intra-region & & & & & & & & & & & & \\
\hline ASEAN & $1.81 * * *$ & $1.79 * * *$ & $1.69 * * *$ & $1.74 * * *$ & $1.64 * * *$ & $1.65 * * *$ & $0.82 * * *$ & $0.81 * * *$ & $0.70 * * *$ & $0.82 * * *$ & $0.65 * * *$ & $0.66^{* * *}$ \\
\hline & $(15.22)$ & (16.34) & (16.19) & (10.18) & (25.28) & (27.18) & $(7.32)$ & $(8.08)$ & ( 7.31) & ( 5.27) & ( 10.76) & (11.73) \\
\hline EU & $0.24 * * *$ & $0.27 * * *$ & 0.10 & 0.12 & $0.24 * * *$ & $0.23 * * *$ & $0.33 * * *$ & $0.37 * * *$ & $0.21 * * *$ & $0.23 * *$ & $0.34 * * *$ & $0.34 * * *$ \\
\hline & ( 2.75) & $(3.35)$ & $(1.25)$ & $(0.92)$ & ( 4.99) & ( 5.14) & ( 4.01$)$ & ( 5.10) & ( 3.01) & $(2.00)$ & $(7.78)$ & $(8.16)$ \\
\hline NAFTA & $0.57 * * *$ & $0.62 * * *$ & $1.09 * * *$ & $1.26 * * *$ & $0.87 * * *$ & $0.92 * * *$ & $-0.49 * *$ & $-0.46^{* *}$ & 0.13 & 0.27 & -0.13 & -0.08 \\
\hline & ( 2.68) & $(3.21)$ & $(5.87)$ & $(4.23)$ & ( 7.51) & $(8.52)$ & $(-2.50)$ & $(-2.62)$ & ( 0.81$)$ & $(1.00)$ & $(-1.27)$ & $(-0.81)$ \\
\hline APEC & & & & & & & $1.23 * * *$ & $1.26 * * *$ & $1.18 * * *$ & $1.21 * * *$ & $1.20 * * *$ & $1.20 * * *$ \\
\hline & & & & & & & (34.57) & (39.91) & (39.06) & (24.82) & (62.94) & (67.45) \\
\hline Adjusted $\mathrm{R}^{2}$ & 0.73 & 0.74 & 0.73 & 0.73 & 0.74 & 0.74 & 0.78 & 0.79 & 0.79 & 0.79 & 0.79 & 0.79 \\
\hline F-Statistic & $1466.5^{* * *}$ & $1528.6 * * *$ & $1500.3 * * *$ & $589.9 * * *$ & $4702.2 * * *$ & $5360.6 * * *$ & $1715.3 * * *$ & $1909.9 * * *$ & $1855.6^{* * *}$ & $732.4 * * *$ & $5599.0 * * *$ & $6400.2 * * *$ \\
\hline Obs & 5927 & 5943 & 5950 & 2380 & 17820 & 20200 & 5927 & 5943 & 5970 & 2380 & 17820 & 20200 \\
\hline
\end{tabular}

Note $* * *, * *$, and $*$ denote $1 \%, 5 \%$, and $10 \%$ level significance respectively. The numbers in parentheses are the t-statstics. Due to the difference of observed years and missing values, the numbers of observations are not constant. The number of observations are as follows; (a) For periods 1983-87, 1988-92 and 1993-97, 35 by 34 countries, by 5 years $=5950$; (b) For the period 1998-99, 35 by 34 countries, by 2 years = 2380; (c) For the period 1983-97, 35 by 34 countries, by 15 years = 17850; (d) For the period 1983-99, 35 by 34 countries and by 17years $=20230$. All regressions estimated using TSP. 
Table 2. Modified Gravity model estimates: trade creation and trade diversion

\begin{tabular}{|c|c|c|c|c|c|c|}
\hline Variable & $1983-87$ & $1988-92$ & $1993-97$ & 1998-99 & $1983-97$ & 1983-99 \\
\hline \multirow[t]{2}{*}{$\bar{C}$} & $-29.57 * * *$ & $-28.43 * * *$ & $-29.48 * * *$ & $-30.12 * * *$ & $-25.81 * * *$ & $-25.93 * * *$ \\
\hline & $(-57.64)$ & $(-59.71)$ & $(-64.79)$ & $(-40.34)$ & $(-102.03)$ & $(-109.92)$ \\
\hline \multirow[t]{2}{*}{ LGDPR } & $0.79 * * *$ & $0.77 * * *$ & $0.78 * * *$ & $0.77 * * *$ & $0.73 * * *$ & $0.73 * * *$ \\
\hline & ( 58.97) & (63.23) & $(67.52)$ & (41.49) & (103.03) & ( 110.27) \\
\hline \multirow[t]{2}{*}{ LGDPP } & $0.78 * * *$ & $0.79 * * *$ & $0.87 * * *$ & $0.90 * * *$ & $0.77 * * *$ & $0.78 * * *$ \\
\hline & ( 58.51) & (64.72) & ( 75.93) & (48.83) & (108.08) & ( 117.39) \\
\hline \multirow[t]{2}{*}{ LPGDPR } & $0.25 * * *$ & $0.19 * * *$ & $0.16 * * *$ & $0.20 * * *$ & $0.17 * * *$ & $0.17 * * *$ \\
\hline & ( 20.13) & (18.25) & (16.98) & (12.78) & (26.97) & (29.03) \\
\hline \multirow[t]{2}{*}{ LPGDPP } & $0.34 * * *$ & $0.19 * * *$ & $0.14 * * *$ & $0.12 * * *$ & $0.19 * * *$ & $0.18 * * *$ \\
\hline & ( 27.48) & (18.34) & $(14.70)$ & $(7.70)$ & ( 30.30$)$ & (30.50) \\
\hline \multirow[t]{2}{*}{ LGAP } & $0.06 * * *$ & $0.04 * * *$ & $-0.02 *$ & -0.02 & $0.01 *$ & 0.01 \\
\hline & $(5.01)$ & ( 3.78) & $(-1.91)$ & $(-1.44)$ & ( 1.92$)$ & $(1.36)$ \\
\hline \multirow[t]{2}{*}{ LDIS } & $-0.65 * * *$ & $-0.59 * * *$ & $-0.60 * * *$ & $-0.62 * * *$ & $-0.63 * * *$ & $-0.63 * * *$ \\
\hline & $(-35.41)$ & $(-35.85)$ & $(-39.75)$ & $(-25.75)$ & $(-63.36)$ & $(-68.13)$ \\
\hline \multirow[t]{2}{*}{ ADJ } & $0.34 * * *$ & $0.46 * * *$ & $0.39 * * *$ & $0.41 * * *$ & $0.39 * * *$ & $0.39 * * *$ \\
\hline & ( 4.53$)$ & ( 6.79) & ( 6.29) & $(4.22)$ & (9.68) & ( 10.43) \\
\hline \multirow[t]{2}{*}{ COM } & $1.02 * * *$ & $1.23 * * *$ & $1.20 * * *$ & $1.31 * * *$ & $1.15^{* * *}$ & $1.18 * * *$ \\
\hline & (20.99) & $(22.62)$ & (23.07) & (17.78) & (37.99) & (41.59) \\
\hline \multicolumn{7}{|l|}{ Intra-regional bias } \\
\hline \multirow[t]{2}{*}{ ASEAN } & $2.26 * * *$ & $2.27 * * *$ & $2.11 * * *$ & $2.35 * * *$ & $2.01 * * *$ & $2.03 * * *$ \\
\hline & ( 19.75) & (21.95) & (22.30) & $(15.53)$ & (32.70) & $(35.50)$ \\
\hline \multirow[t]{2}{*}{ EEC } & $0.29 * * *$ & $0.27 * * *$ & 0.11 & 0.11 & $0.34 * * *$ & $0.33 * * *$ \\
\hline & $(3.34)$ & $(3.47)$ & ( 1.49$)$ & $(0.96)$ & ( 7.26) & ( 7.55) \\
\hline \multirow[t]{2}{*}{ NAFTA } & $0.52 * * *$ & $0.60 * * *$ & $1.12 * * *$ & $1.29 * * *$ & $0.98 * * *$ & $1.04 * * *$ \\
\hline & $(2.58)$ & (3.28) & $(6.66)$ & $(4.90)$ & ( 8.96) & ( 10.22) \\
\hline \multicolumn{7}{|l|}{$\begin{array}{l}\text { Extra-regional bias } \\
\text { (imports to) }\end{array}$} \\
\hline \multirow[t]{2}{*}{ imASEAN } & $0.76 * * *$ & $0.92 * * *$ & $1.02 * * *$ & $0.98 * * *$ & $0.83 * * *$ & $0.83 * * *$ \\
\hline & ( 16.27) & (21.51) & $(26.25)$ & (15.68) & ( 32.64) & (35.41) \\
\hline \multirow[t]{2}{*}{ imEEC } & $0.28 * * *$ & $0.20 * * *$ & $0.20 * * *$ & $0.29 * * *$ & $0.30 * * *$ & $0.31 * * *$ \\
\hline & $(6.50)$ & $(5.34)$ & $(5.55)$ & $(5.28)$ & ( 13.32) & ( 14.64) \\
\hline \multirow[t]{2}{*}{ imNAFTA } & $-0.35 * * *$ & $-0.23 * * *$ & 0.01 & $0.23 * * *$ & $-0.07 * *$ & $-0.02 * * *$ \\
\hline & $(-5.82)$ & $(-4.41)$ & $(0.28)$ & $(1.28)$ & $(-2.06)$ & $(-0.60)$ \\
\hline \multicolumn{7}{|l|}{ (exports from) } \\
\hline \multirow[t]{2}{*}{ exASEAN } & $0.79 * * *$ & $0.81 * * *$ & $0.91 * * *$ & $1.28 * * *$ & $0.77 * * *$ & $0.82 * * *$ \\
\hline & ( 16.97) & (19.05) & (23.55) & (20.59) & ( 30.32) & (34.74) \\
\hline \multirow[t]{2}{*}{ exEEC } & $0.22 * * *$ & $0.19 * * *$ & $0.21 * * *$ & $0.21 * * *$ & $0.29 * * *$ & $0.29 * * *$ \\
\hline & $(5.18)$ & $(4.90)$ & ( 5.87) & $(3.75)$ & ( 12.56) & $(13.49)$ \\
\hline exNAFTA & $-0.41 * * *$ & $-0.43 * * *$ & $-0.57 * * *$ & $-0.58 * * *$ & $-0.34 * * *$ & $-0.36 * * *$ \\
\hline & $(-6.92)$ & $(-8.12)$ & $(-11.71)$ & $(-7.56)$ & $(-10.88)$ & $(-12.17)$ \\
\hline Adjusted $\mathrm{R}^{2}$ & 0.76 & 0.77 & 0.78 & 0.79 & 0.77 & 0.78 \\
\hline F-statisitics & $1095.6 * * *$ & $1193.5^{* * *}$ & $1273.4 * * *$ & $541.02 * * *$ & $3566.8 * * *$ & $4114.5^{* * *}$ \\
\hline Observations & 5927 & 5943 & 5950 & 2380 & 17820 & 20200 \\
\hline
\end{tabular}

Note $* * *, * *$, and $*$ denote $1 \%, 5 \%$, and $10 \%$ level significance respectively. 
Table 3. Modified Gravity model estimates: ASEAN bilateral trade

\begin{tabular}{|c|c|c|c|c|c|c|}
\hline Variable & $1983-87$ & 1988-92 & 1993-97 & 1998-99 & 1983-97 & 1983-99 \\
\hline \multirow[t]{2}{*}{$\mathrm{C}$} & $-28.71 * * *$ & $-26.41 * * *$ & $-29.93 * * *$ & $-33.23 * * *$ & $-22.76 * * *$ & $-23.48 * * *$ \\
\hline & $(-28.00)$ & $(-27.33)$ & $(-32.40)$ & $(-20.90)$ & $(-44.48)$ & $(-48.68)$ \\
\hline \multirow[t]{2}{*}{ LGDPR } & $0.89 * * *$ & $0.85 * * *$ & $0.88 * * *$ & $0.97 * * *$ & $0.77 * * *$ & $0.78 * * *$ \\
\hline & $(35.40)$ & $(35.53)$ & (39.31) & $(25.52)$ & $(57.50)$ & $(62.25)$ \\
\hline \multirow[t]{2}{*}{ LGDPP } & $0.94 * * *$ & $0.89 * * *$ & $0.94 * * *$ & $0.96 * * *$ & $0.82 * * *$ & $0.82 * * *$ \\
\hline & (37.47) & (37.71) & (41.72) & (25.44) & (61.34) & (65.84) \\
\hline \multirow[t]{2}{*}{ LPGDPR } & $0.63 * * *$ & $0.48 * * *$ & $0.38 * * *$ & $0.38 * * *$ & $0.42 * * *$ & $0.41 * * *$ \\
\hline & $(25.92)$ & $(23.06)$ & (21.19) & (13.28) & (34.81) & (36.88) \\
\hline \multirow[t]{2}{*}{ LPGDPP } & $0.61 * * *$ & $0.45 * * *$ & $0.37 * * *$ & $0.21 * * *$ & $0.40 * * *$ & $0.37 * * *$ \\
\hline & $(25.15)$ & (21.77) & $(20.50)$ & $(7.46)$ & (33.20) & (33.32) \\
\hline \multirow[t]{2}{*}{ LGAP } & $-0.10 * * *$ & $-0.14 * * *$ & $-0.11 * * *$ & $-0.05^{*}$ & $-0.09 * * *$ & $-0.08 * * *$ \\
\hline & $(-4.08)$ & $(-6.78)$ & $(-6.06)$ & $(-1.70)$ & $(-6.89)$ & $(-7.00)$ \\
\hline \multirow[t]{2}{*}{ LDIS } & $-1.84 * * *$ & $-1.58 * * *$ & $-1.29 * * *$ & $-1.13 * * *$ & $-1.49 * * *$ & $-1.44 * * *$ \\
\hline & $(-37.09)($ & $(-34.03)$ & $(-30.55)$ & $(-16.06)$ & $(-53.70)$ & $(-55.66)$ \\
\hline \multirow[t]{2}{*}{$\mathrm{ADJ}$} & $-1.20 * * *$ & $-0.63 * * *$ & $-0.44 * *$ & -0.25 & $-0.64 * * *$ & $-0.60 * * *$ \\
\hline & $(-5.36)$ & $(-3.02)$ & $(-2.27)$ & $(-0.81)$ & $(-5.06)$ & $(-5.08)$ \\
\hline \multirow[t]{2}{*}{ COM } & $0.89 * * *$ & $1.03 * * *$ & $1.11 * * *$ & $1.37 * * *$ & $1.06 * * *$ & $1.10 * * *$ \\
\hline & (11.37) & (10.46) & (13.52) & (12.07) & (20.69) & (23.34) \\
\hline \multirow[t]{2}{*}{ ASEAN } & $0.34 * *$ & $0.35 * * *$ & $0.51 * * *$ & $0.84 * * *$ & $0.29 * * *$ & $0.35 * * *$ \\
\hline & $(2.40)$ & $(2.66)$ & ( 4.19) & $(4.20)$ & ( 3.61) & ( 4.68) \\
\hline Adjusted $\mathrm{R}^{2}$ & 0.74 & 0.73 & 0.76 & 0.75 & 0.75 & 0.75 \\
\hline F-statisitics & $497.6 * * *$ & $487.7 * * *$ & $564.3 * * *$ & $217.2 * * *$ & $1591.3 * * *$ & $1820.9 * * *$ \\
\hline Observations & 1600 & 1600 & 1600 & 640 & 4800 & 5440 \\
\hline
\end{tabular}

Note $* * *, * *$, and $*$ denote $1 \%, 5 \%$, and $10 \%$ level significance respectively. 


\section{References}

Adams, F. G. and Park, I. (1995), Measuring the Impact of AFTA: An Application of a Linked CGE System, Journal of Policy Modelling, Vol. 17(4), pp. 325-365.

Aitken, N.D. (1973), The Effect of the EEC and EFTA on European Trade: a Temporal Cross-Section Analysis, American Economic Review, Vol. 63, pp. 881-92.

Anderson, J. E. (1979), A theoretical foundation for a gravity equation, American Economic Review, Vol. 69, pp. 106-116.

Anwar, D.F. (1994), Indonesia in ASEAN: Foreign Policy and Regionalism. New York: St. Martin's Press.

Ariff, M. (1994), Open Regionalism á la ASEAN, Journal of Asian Economics, Vol. 5, pp. 99-117.

Arndt, S. W. (2001), Production Networks in an Economically Integrated Region, ASEAN Economic Bulletin Vol. 18, No. 1, April, pp. 24-34.

ASEAN Secretariat (1995), AFTA Reader, Jakarta: ASEAN Secretariat.

ASEAN Secretariat (2002), ASEAN Economic Cooperation - Trade and AFTA, http://www.aseansec.org/.

Asian Development Bank (2002). Asian Development Outlook 2002, http://www.adbc.org/.

Athukorala, P.C. and Menon, J. (1997), AFTA and the Investment-Trade Nexus in ASEAN, World Economy, Vol. 20(2), March, pp. 159-174.

Balassa, B. (1967), Trade creation and trade diversion in the European Common Market. Economic Journal, 77, pp.1-21.

Balassa, B. (1974), Trade creation and trade diversion in the European Common Market: An appraisal of the evidence. Manchester School of Economic and Social Studies, 42, pp.93-135.

Balassa, B. (ed.) (1975), European Economic Integration. Amsterdam: North-Holland.

Bayoumi, T., and Eichengreen, B. (1997). Is regionalism simply a diversion? Evidence from the evolution of the EC and EFTA. In T. Ito and A. O. Krueger (Eds.), Regionalism versus Multilateral Trade Arrangements. Chicago: University of Chicago Press.

Bergsten, F. (1997), Open Regionalisam, Institute for International Economics 
Working Paper 97-3.

Bergstrand, J. H. (1985), The gravity equation in international trade: Some microeconomic foundations and empirical evidence, Review of Economics and Statistics, Vol. 67, pp. 474-481.

Bende-Nabende, A., Ford, J. L. and Slater, J. R., (2001), FDI, Regional Economic Integration and Endogenous Growth: Some evidence from Southeast Asia, Pacific Economic Review, Vol 6, No. 3, pp. 1-18.

Bhagwati, J. (1991). The World Trading System at Risk. Princeton, NJ: Princeton U. Press.

Brülhart, M. and Thorpe, M. (2000), Intra-Industry Trade and Adjustment in Malaysia: Puzzling Evidence, Applied Economics Letters, Vol. 7, No. 11, pp. 729-733.

Clarete, R., Edmonds, C. and Seddon, J. (forthcoming), Asian Regionalism and its Effects of Trade in the 1990's. ABD Economics and Research Department Working Paper.

Deardorff, A.V. (1984), Testing Trade Theories and Predicting Trade Flows, in Jones, R.W. and Kenon, P (eds) Handbook of International Economics, Volume 1, Elsevier Science Publishers, Amerstam.

DeRosa, A. Dean (1995), Regional Trading Arrangements among Developing Countries: The ASEAN example, Research Report 103, International Food Policy Research Institute, Washington D.C.

Drysdale, P. D. (1967), Japan, Australia and New Zealand: the prospects for Western Pacific integration, Economic Record, Vol. 45(111), September, pp.321-342.

Elbadawi, I. (1997), The impact of Regional Trade and Monetary Schemes on Intra-subSaharan Africa Trade, in A. Oyejide, I. Elbadawi, and P. Collier (eds.) Regional Integration and Trade Liberalization in SubSaharan Africa Volume 1 : Framework, Issues and Methodological Perspectives, London : Macmillan Press Ltd., pp. 210-255.

Endoh, M. (1999), Trade creation and trade diversion in the EEC, the LAFTA and the CMEA: 1960-1994, Applied Economics, 31, pp.207- 216.

Endoh, M. (2000) The transition of postwar Asia-Pacific trade relations, Journal of Asian Economics 10, pp.571-589.

Ethier, Wilfred J. (1998), Regionalism in a Multilateral World, Journal of Political Economy, Vol. 106, no.6, pp.1214-1245. 
Evenett, S.J. and Keller, W. (2002), On Theories Explaining the Success of the Gravity Equation, Journal of Political Economy, Vol. 110, no. 2, pp. 281-316.

Frankel, J. A. (1993), Is Japan Creating a yen block in East Asia and the Pacific?, in Jeffrey A. Frankel and Miles Kahler (eds.), Regionalism and Rivalry: Japan and the United States in Pacific Asia, Chicago: University of Chicago Press, pp. 53-85.(reprinted in R. Garnaut and P. Drysdale (eds.), Asia-Pacific Regionalism: Readings in International Economic Relations, Sydney: Harper Educational Publishers, pp. 227-249.

Frankel, J., Stein, E., \& Wei, S. (1995), Trading blocs and the Americas: the natural, the unnatural, and the super-natural, Journal of Development Economics Vol. 47 (1), 61-95.

Frankel, J. A. (1997), Regional Trading Blocs in the World Economic System. Washington, DC: Institute for International Economics.

Frankel, J. A. and Wei, S.J (1998), Regionalization of World Trade and Currencies: Economics and Politics, in Jeffrey A. Frankel ed., The Regionalization of the World Economy, Chicago and London: The University of Chicago Press, pp.189-219.

Garnaut, R. and Drysdale, P. (1994) Asia-Pacific Regionalism: The Issues, in R. Garnaut and P. Drysdale (eds.), Asia-Pacific Regionalism: Readings in International Economic Relations, Sydney: Harper Educational Publishers, pp. $1-7$.

Greenaway, D. and Milner, C. (1986), The Economics of Intra-Industry Trade, Oxford: Blackwell.

Guiheux, G. and Lecler, Y. (2000), Japanese Car Manufacturers and Component Makers in the ASEAN Region: a Case of Expatriation under Duress- or a Strategy of Regionally Integrated Production?", in John Humphrey, Yveline Lecler and Mario Sergio Salerno (eds.), Global Strategies and Local Realities: The Auto Industry in Emerging Markets, London: Macmillan Press Ltd, pp. 207-233.

Hamilton, C. B. and Winters, L. A. (1992) Opening up international trade with Eastern Europe, Economic Policy, pp. 77-116.

Helpman, E., and Krugman, P. A. (1985), Market Structure and Foreign Trade, Cambridge: MIT Press.

Hine, R. C. (1994) International Economic Integration. In David Greenaway and L. Alan Winte (eds), Surveys in international trade. Oxford: Blackwell. 
Imada, P., Montes, M. and Naya, S. (1991) A Free Trade Area - Implications for ASEAN, Singapore: ASEAN Economic Research Unit, Institute Southeast Asian Studies (ISEAS).

Institute of Development Studies (IDS) (1999), Regional Trade Agreement, Trade \& Investment, Background briefing No.2.

Johnson, H. G. (1962), Money Trade and Economic Growth - Survey Lectures in Economic Theory, George Allen and Urwin, London.

Khalifah, N. A. (1996), AFTA and Intra-Industry Trade, ASEAN Economic Bulletin Vol. 12, No.3, pp. 351-368.

Kruger, A. (1999), Trade creation and trade diversion under NAFTA, NBER Working Paper series, No.7429.

Krugman, P. R. (1991) Is Bilateral Bad? In E. Helpman and A. Razim E (eds.), International Trade and Policy, Cambridge: MIT Press.

Lawrence, R. (1991), Emerging Regional Arrangements: Building Blocks or Stumbling Blocks? In Finance and the International Economy, edited by R. O'Brian. The AMEX Bank Review Prize Essays. United Kingdom: Oxford University Press.

Linder, S. B. (1961), An Essay on Trade and Transformation, Stockholm: Almqvist \& Wiksell.

Linneman, H. (1966), An Economic Study of International Trade Flows, Amsterdam: North-Holland.

Madani, D. (2001), Regional Integration and Industrial Growth among Developing Countries: The Case of Three ASEAN Members, World Bank Working Paper No.2697, New York: World Bank.

Menon, J. (1996), Adjusting towards AFTA: The Dynamics of Trade in ASEAN, Singapore: Institute of Southeast Asian Studies.

Ng, F. and Yeats, A. (1999), Production Sharing in East Asia: Who Does What for Whom and Why?, Policy Research Working Paper 2197, The World Bank, Development Research Group, Washington D.C.

OECD (Organisation for Economic Cooperation and Development) (1993) Regional Integration and Developing Countries. Paris: OECD.

Pangestu, M., Soesastro, H. and Ahmad, M. (1992), A new look at intra-ASEAN economic cooperation, ASEAN Economic Bulletin, Vol. 8(3), pp. 333-352.

Park, D. (1999), The Prospects for Further Economic Integration in ASEAN, Journal 
of Economic Integration, Vol. 14(3), September, pp. 382-418.

Pomfret, R (1996), ASEAN: Always at the Crossroads? Journal of the Asia Pacific Economy, Vol. 1 (3): 365-90.

Pöyhönen, P. (1963), A tentative model for the volume of trade between countries, Welwirtschaftliches Archiv, Vol. 90, pp. 93-99.

Prewo, W.E. 1974. Integration Effects in the EEC: An Attempt at Quantification in a General Equilibrium Framework. European Economic Review 5: 379-405.

Sanso, M., Cuairan, R. and Sanz, F. (1993), Bilateral trade flows, the gravity equation, and foundation form, Review of Economics and Statistics, Vol. 75, pp. 266-275.

Sharma, S. C., and Chua, S. Y. (2000), ASEAN: economic integration and intra-regional trade, Applied Economics Letters, Vol. 7, pp. 165-169.

Soloaga, Isidro and Winters, L. Alan (2001) Regionalism in the nineties: What effect on trade?, The North American Journal of Economics and Finance, Vol. 12, pp.1-29.

Summers, L. (1991), Regionalism and the World Trading System. In Policy Implications of Trade and Currency Zones. Wyoming: Federal Reserve Bank of Kansas City.

Tan, G. (1992), ASEAN Preferential Trading Arrangements: An Overview, The ASEAN Reader, Singapore: Institute of Southeast Asian Studies, pp. 237-241.

Tinbergen, J. (1962), Shaping the World Economy: Suggestions for an International Economic Policy, New York: The Twentieth Century Fund.

Todaro, P. M. (2000), Economic Development 7th (ed.). Harlow: Addison-Wesley.

Truman, E.M. (1969), The European Economic Community: Trade creation and trade diversion, Yale Economic Essays, 9, pp.201-257.

Verdoorn, P. J. and Schwartz, A. N. R. (1972), Two alternative estimates of the effects of EEC and EFTA on the pattern of trade. European Economic Review, Vol. 3, pp.291-335.

Viner, J. (1950), The Customs Union, New York: Carnegie Endowment for International Peace.

World Bank (1999), Trade Blocs, New York: Oxford University Press.

WTO (World Trade Organisation) (2001), The WTO Annual Report 2001, Geneva: WTO.

Yamazawa, I. (1992), On Pacific Economic Integration, The Economic Journal Vol. 102, no. 415 (November), pp. 1519-29. 


\section{Appendix A}

\section{Timetable for Accelerating AFTA (CEPT Scheme)}

\begin{tabular}{|c|c|c|c|c|c|c|}
\hline & Definition & & $\begin{array}{l}1992 \text { Protocol } \\
\text { igned in Jan.1992) } \\
\text { gun on 1.Jan.1993) }\end{array}$ & $\begin{array}{c}1995 \text { Protocol } \\
\text { (Signed in Dec.1995) } \\
\text { (Begun on 1.Jan.1996) }\end{array}$ & $\begin{array}{l}\text { Some progress after } 1995 \text { protocol } \\
\text { including acceptance of new member }\end{array}$ & $\begin{array}{l}\text { Coverage } \\
\text { in 2001 CEPT } \\
\text { Product List }\end{array}$ \\
\hline \multirow[t]{5}{*}{$\begin{array}{l}\text { Inclusion } \\
\text { List } \\
\text { (INL) }\end{array}$} & \multirow{5}{*}{$\begin{array}{l}\text { Immediate } \\
\text { liberalization through } \\
\text { reduction in } \\
\text { intra-regional (CEPT) } \\
\text { tariff rates, removal of } \\
\text { quantitative } \\
\text { restrictions and other } \\
\text { non-tariff barriers }\end{array}$} & \multicolumn{2}{|c|}{$\begin{array}{l}\text { Covering all manufactured good (not } \\
\text { including unprocessed agricultural } \\
\text { product) }\end{array}$} & $\begin{array}{l}\text { Covering all manufactured good } \\
\text { (including unprocessed } \\
\text { agricultural product) }\end{array}$ & & \multirow[t]{5}{*}{$\begin{array}{l}55,680 \text { tariff line } \\
\text { representing } \\
84.74 \% \text { of all. }\end{array}$} \\
\hline & & \multirow[t]{2}{*}{$\begin{array}{l}\text { Fast } \\
\text { Track }\end{array}$} & $\begin{array}{l}\text { Present rate }<20 \% \\
\rightarrow 0-5 \% \text { by } 1.12000\end{array}$ & $\rightarrow 0-5 \%$ by 1.1 .1998 & \multirow{4}{*}{$\begin{array}{l}\text { For original six countries, according to } \\
1998 \text { agreement, } \\
85 \% \text { of all INL: } 0-5 \% \text { by } 1.1 .2000 \text {. } \\
90 \% \text { of all INL: } 0-5 \% \text { by } 1.1 .2001 \text {. } \\
100 \% \text { of all INL: } 0-5 \% \text { by } 1.1 .2002 \text {. } \\
\text { with flexibility } \\
\text { For Vietnam, reduced to } 0-5 \% \text { by } 2006 \\
\text { For Laos and Myanmar by } 2008 \\
\text { For Cambodia by } 2010\end{array}$} & \\
\hline & & & $\begin{array}{l}\text { Present rate }=20 \% \\
\rightarrow 0-5 \% \text { by } 1.1 .2003\end{array}$ & $\rightarrow 0-5 \%$ by 1.1 .2000 & & \\
\hline & & \multirow[t]{2}{*}{$\begin{array}{l}\text { Normal } \\
\text { Track }\end{array}$} & $\begin{array}{l}\text { Present rate }<20 \% \\
\rightarrow 0-5 \% \text { by } 11.2003\end{array}$ & $\rightarrow 0-5 \%$ by 1.1 .2000 & & \\
\hline & & & $\begin{array}{l}\text { Present rate }=20 \% \\
\rightarrow 20 \% \text { within } 5-8 \text { years } \\
0-5 \% \text { by } 1.1 .2008\end{array}$ & $\begin{array}{r}\rightarrow 20 \% \text { by } 1.1 .1998 \\
0-5 \% \text { by } 1.1 .2003\end{array}$ & & \\
\hline $\begin{array}{l}\text { Temporary } \\
\text { Exclusion } \\
\text { List } \\
(\text { TEL) }\end{array}$ & $\begin{array}{l}\text { Temporarily excluded } \\
\text { from liberalisation, but } \\
\text { have to be transferred } \\
\text { into the Inclusion List }\end{array}$ & \multicolumn{2}{|c|}{$\begin{array}{l}\text { Tariff not removed until 31.12.2000, } \\
\text { but to be reviewed }\end{array}$} & $\begin{array}{l}\text { Gradually transferred to INL, for } \\
\text { original six countries, since } 1996\end{array}$ & $\begin{array}{l}\text { Gradually transferred to INL, } \\
\text { for Vietnam, since } 1999 \\
\text { for Laos and Myanmar, since } 2001 \\
\text { for Cambodia, beginning in } 2003\end{array}$ & $\begin{array}{l}8,660 \text { tariff lines } \\
\text { representing } \\
\text { about } 13.4 \% \text { of } \\
\text { all }\end{array}$ \\
\hline $\begin{array}{l}\text { Sensitive } \\
\text { List }\end{array}$ & $\begin{array}{l}\text { The commitment to } \\
\text { reduce tariffs, remove } \\
\text { quantitative } \\
\text { restrictions and other } \\
\text { non-tariff barriers is } \\
\text { extended. }\end{array}$ & \multicolumn{2}{|c|}{ Tariff not removed } & $\begin{array}{l}\text { Phased in CEPT, beginning } \\
2001-03 \text {, reduced to } 0-5 \% \text {, for } \\
\text { original six countries, by } 2010\end{array}$ & $\begin{array}{l}\text { Phased in CEPT, reduced to } 0-5 \%, \\
\text { for Vietnam by } 2013 \\
\text { for Laos an Myanmar by } 2015 \\
\text { for Cambodia by } 2017 \\
\text { (note: remaining "Highly sensitive List" } \\
\text { which need special arrangement for } \\
\text { liberalisation ) }\end{array}$ & $\begin{array}{l}360 \text { tariff lines } \\
\text { making up } \\
0.55 \% \text { of all } \\
\text { tariff lines }\end{array}$ \\
\hline $\begin{array}{l}\text { General } \\
\text { Exclusion } \\
\text { List }\end{array}$ & $\begin{array}{l}\text { Permanently excluded } \\
\text { from FTA for reasons } \\
\text { of national security, } \\
\text { protection of human, } \\
\text { animal or plant life and } \\
\text { health and articles of } \\
\text { artistic, historic and } \\
\text { archaeological value }\end{array}$ & \multicolumn{4}{|c|}{ Tariff not removed } & $\begin{array}{l}829 \text { tariff lines } \\
\text { representing } \\
\text { about } 1.28 \% \text { of } \\
\text { all tariff lines }\end{array}$ \\
\hline
\end{tabular}

(Source) ASEAN Secretariat 


\section{Appendix B}

(1) Variable and Data Source

\begin{tabular}{|l|l|}
\hline \multicolumn{1}{|c|}{ Variable } & \multicolumn{1}{|c|}{ Source } \\
\hline Imports and exports & $\begin{array}{l}\text { Australian National University and Victoria University of Technology, } \\
\text { NAPES database and IMF Direction of Trade Statistics Ye arbook }\end{array}$ \\
\hline GDP & World Bank, World Development Indicators 2001 (CD-ROM) \\
\hline Per capita GDP & $\begin{array}{l}\text { Calculated by GDP/Population from World Bank, World Development } \\
\text { Indicators 2001 (CD-ROM) }\end{array}$ \\
\hline $\begin{array}{l}\text { Distance } \\
\text { index }\end{array}$ & $\begin{array}{l}\text { Australian National University and Victoria University of Technology, } \\
\text { NAPES database. }\end{array}$ \\
\hline
\end{tabular}

(2) Country Coverage: The following 35 countries are selected based on existing studies and data availability.

\begin{tabular}{|l|l|}
\hline \multicolumn{1}{|c|}{ Regional group } & \multicolumn{1}{|c|}{ Member countries } \\
\hline APEC & $\begin{array}{l}\text { Australia, Canada, Chile, China, Indonesia, Japan, Korea, Malaysia, } \\
\text { Mexico, New Zealand, Philippines, Singapore, Thailand and United States } \\
\text { (other members include Hong Kong, Papua New Guinea, Peru, Russian } \\
\text { Federation, Viet Nam). }\end{array}$ \\
\hline ASEAN & $\begin{array}{l}\text { Indonesia, Malaysia, the Philippines, Thailand and Singapore (other } \\
\text { members include Brunei Darussalam, Cambodia, Lao PDR, Myanmar and } \\
\text { Viet Nam). }\end{array}$ \\
\hline EU & $\begin{array}{l}\text { Belgium, France, Germany, Ireland, Italy, Netherlands and UK (other } \\
\text { members include Austria, Denmark, Greece, Finland, Luxemburg, } \\
\text { Portugal, Spain and Sweden). }\end{array}$ \\
\hline NAFTA & $\begin{array}{l}\text { United States, Canada and Mexico. } \\
\text { Denmark, Finland, Greece, Norway, Portugal, Spain, Sweden and } \\
\text { Switzerland }\end{array}$ \\
\hline
\end{tabular}




\section{Appendix C. ASEAN real exchange rates}
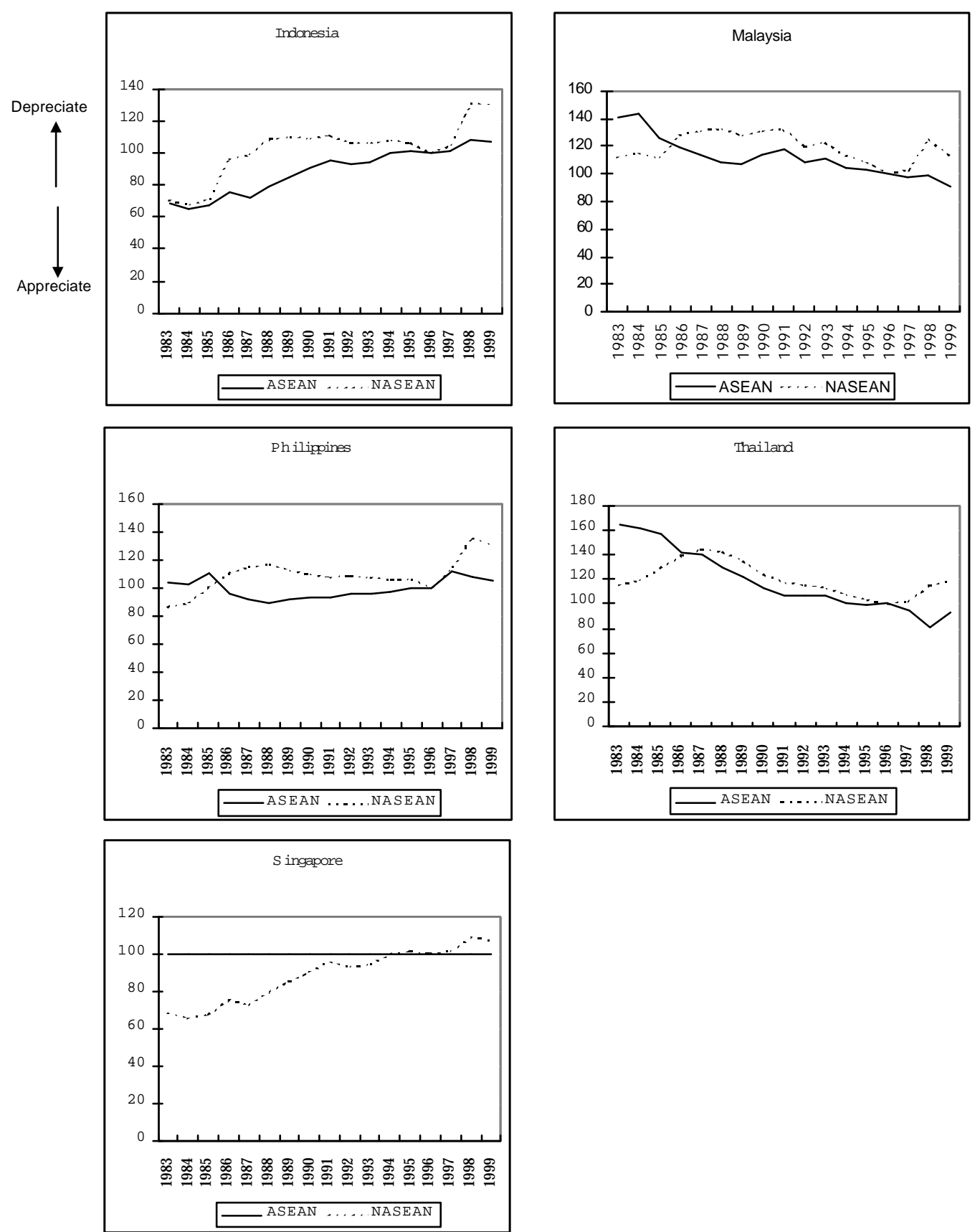

\section{Relative Real Exchange Rate of ASEAN countries}

Note. Relative exchange rates are calculated as follows:

(1) Country $i$ 's relative real exchange rate to country $j$ was defined as the local currency value of 1 $j$ 's local currency, multiplied by the $j$ 's GDP deflator and devided by country $i$ 's GDP deflator, where $i$ is each ASEAN country and $j$ is our every sample country.

(2) Country $i$ 's relative real exchange rate to ASEAN was calculated by weighting an each relative real exchange rate by the share of $i$ 's trade with each ASEAN country in $i$ 's trade with the ASEAN total and summing.

(3) Similarly, country $i$ 's relative real exchange rate to non ASEAN member was calculated by weighting an each relative real exchange rate by the share of $i$ 's trade with each non ASEAN country in $i$ 's trade with the non ASEAN members total and summing. 